\section{ECONOMICS}

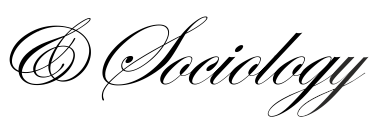

Egerová, D., Kutlák, J., \& Eger, L. (2021). Millennial job seekers' expectations: How do companies respond?. Economics and Sociology, 14(1), 46-60. doi:10.14254/2071-789X.2021/14-1/3

\title{
MILLENNIAL JOB SEEKERS' EXPECTATIONS: HOW DO COMPANIES RESPOND?
}

\author{
Dana Egerová \\ University of West Bohemia, \\ Plzeñ, Czech Republic \\ E-mail:egerova@,kpm.zcu.cz \\ ORCID 0000-0003-1824-9288

\section{Jiří Kutlák \\ University of West Bohemia, \\ Plzeñ, Crech Republic \\ E-mail:kutlak@kpm.zcu.cz \\ ORCID 0000-0002-6866-6525}

\section{Ludvík Eger} \\ University of West Bohemia, \\ Plzeñ, Czzech Republic \\ E-mail:_egen@,kmo.zcu.cz. \\ ORCID 0000-0002-5437-3297
}

Received: January, 2020

1st Revision: September, 2020

Accepted: March, 2021

DOI: $10.14254 / 2071-$

789X.2021/14-1/3

JEL Classification: M12, M51
ABSTRACT. This study explores the expectations that Millennial job seekers have regarding their future employment as the economic situation changes. This study also explores to what extent companies in Czech Republic respond to these expectations. The theoretical framework guiding this study is the anticipatory psychological contract (APC). A mixed-method research design is employed using the Delphi method to investigate the expectations of final-year business university students and a content analysis of companies' profiles. The research was conducted in Czech Republic in the academic year 2018/2019. The results indicate that business students give the highest importance to the factors such as career development, financial reward and work-life balance when searching for an employer. Furthermore, the findings show that companies only partially respond to student expectations and meet them insufficiently, as indicated by their company profiles. The study contributes to the literature on anticipatory psychological contracts by using APC dimensions as a relevant framework to assess the fulfilment of Millennials' workplace expectations. Moreover, the study provides useful information for companies, HR managers, and recruitment specialists to design and implement effective recruiting strategies.
Keywords: anticipatory psychological contract, Millennials, workplace expectations, Delphi method, content analysis, Czech Republic.

\section{Introduction}

In the contemporary labour market, Generation $\mathrm{Y}$ also referred to as the Millennials (born between 1982 and 2000) is the fastest-growing workforce segment that represents a significant proportion of today's workforce (Moore, Grunberg \& Krause, 2015; Ramesh \& Vasuki, 2013). Since 2020, this generation constitutes over a third of the global workforce (Manpower Group, 2016). Millennials have grown up in a different world than the generations that preceded them (Baby Boomers, Generation X). Internet and other technologies have become an integral part of their life (Wong et al., 2008). This generation is more technically literate, better educated and highly informed than the previous generations (Eisner, 2005). They 
appreciate diversity and are considered as skilled multitaskers (Weber, 2017). They are also labelled as proactive and adaptable generation (De Hauw \& De Vos, 2010). Hence, Generation Y's entrance to the workplace presents many challenges for organisations in which high-skilled and high-performing workers are assets (Eisner, 2005).

There is growing evidence that the Millennial talent that possesses new and unique skills and capabilities has become one of the key factors of organisational success and an important source of competitive advantage in the current globalised business environment (Zupan, Mihelič \& Aleksić, 2018). It is also obvious that, because of the ageing workforce, the struggle for talent, and the shortage of skilled workers, companies are under increasing pressure to attract and retain Millennials to meet current and future organisational goals. As indicated by (Ruchika \& Prasad, 2019), due to the positive economic climate before the COVID-19 pandemic, the demand for qualified workers was increasing faster than ever. Thus, companies need to focus on recruiting and retaining this generation of workers (Lowe, Levitt \& Wilson, 2011; Todorović \& Pavićević, 2016).

To attract the Millennial generation successfully, it is more important than ever for companies to understand their employment expectations (Zupan, Mihelič \& Aleksić, 2018). Some studies have found that, unlike previous generations, the Millennials have significantly different expectations of the future workplace ( $\mathrm{Ng}$, Schweitzer \& Lyons, 2010; Lowe, Levitt \& Wilson, 2011). A better understanding of these expectations will provide companies with critical information to develop and implement effective recruitment and retention strategies (De Vos, De Stobbeleir \& Meganck, 2009; Ng, Schweitzer \& Lyons, 2010). Conversely, failure to meet these expectations can negatively affect prospective employee intentions of joining an organisation. Some authors (De Vos, De Stobbeleir \& Meganck, 2009; Gresse, Linde \& Schalk, 2013) argue that a useful concept to better understand Millennials' expectations is the psychological contract; more specifically, the anticipatory psychological contract (APC).

Furthermore, some researchers have suggested that Millennials' expectations of future employment can be influenced by the socioeconomic contextual factors (De Hauw \& De Vos, 2010; Dziewanowska, Pearce \& Zupan, 2016). However, most studies regarding Millennials' expectations were carried out in the U.S. and Western European context. Moreover, they were conducted during the periods of economic crisis and recession ( $\mathrm{Ng}$, Schweitzer \& Lyons, 2010; Parry \& Urwin, 2011; Dziewanowska, Pearc \& Zupan, 2016). Hence, this study is conducted in the context of Czech Republic, which is characterised by a prosperous market economy and low unemployment. More particularly, the unemployment rate has continued to decrease and, at below 3\%, was among the lowest among the OECD countries (OECD, 2020). Additionally, the youth unemployment rate (young people under 25) of $6.3 \%$ was one of the lowest in the EU28 (Eurostat, 2018). However, the growth of Czech economy is negatively influenced by the limited availability of the local workforce as the population in the 15-64 years age group has declined steadily. This decline is mainly because of the ageing Czech population, which is getting older faster than most European countries (OECD, 2018). Moreover, Czech labour market is shifting towards higher-skilled jobs. From 1997 to 2017, Czech labour market shifted from medium-skilled towards high-skilled jobs, while such sectors as manufacturing, IT, and business services continue to expand (CEDEFOP, 2018). Thus, it is expected that the demand for a highly skilled workforce will grow, and Czech companies will face increasing difficulties in finding the needed workforce.

The purpose of the present study is to explore the expectations the Millennials have regarding their future employment and to what extent the selected companies in Czech Republic respond to these expectations. The theoretical framework guiding this study is the Anticipatory Psychological Contract. More particularly, the dimensional model of APC (Lub et al., 2016) 
and APC structural model (Gresse, Linde \& Schalk, 2013) are adopted. This study focuses on the final-year business university students seeking their first jobs.

The study contributes to the literature on generations, particularly Millennials, in the workplace, by examining the actual expectations of this group. Next, the study contributes to the literature on APC by using APC categories as a relevant concept to assess the fulfilment of the Millennial workplace expectations from the employers' perspective. Finally, the study provides useful information for HR managers and recruitment specialists to help them design the most effective recruitment process.

The paper proceeds as follows. First, a literature review is conducted regarding the APC and the expectations of the Millennials. Second, the research design is explained. Third, the findings are reported and discussed. Finally, the conclusions, implications, as well as the scope for future research, are discussed. The study's limitations are also discussed.

\section{Literature review}

\subsection{Workplace Expectations and the Millennials}

Generation Y (born between 1982 and 2000 and also referred to as Millennials, Echo Boomers, Nexters, and Generation Me) are usually defined as a demographic cohort following Generation X (Moore, Grunberg \& Krause, 2015; Dziewanowska, Pearce \& Zupan, 2016). Millennials have grown up in economic, social, and political contexts that are distinct from those of previous generations; thus, they are expected to have different expectations related to work and employment (Lowe, Levitt \& Wilson, 2011; Mičík \& Mičudová, 2018; Thompson \& Gregory, 2012). According to Linde and Greece (2014), expectations refer to the individual's anticipation of receiving something. Sutton and Griffin (2004) use the term 'pre-entry expectations' to describe prospective employees' expectations formed prior to organisational entry. Moore, Grunberg and Krause (2015) define expectations as individuals' beliefs about what the company will provide in areas such as rewards, benefits, career development, and job security. The failure of organisations to meet the expectations of potential employees may lower their intention to choose and apply to the organisation (Gresse, Linde \& Schalk, 2013). Therefore, it has become a challenge for organisations to understand the expectations of their future employees and work on these expectations to attract the right candidates.

$\mathrm{Ng}$, Schweitzer, and Lyons (2010) claim that Millennials have higher expectations of future employment than did previous generations. De Hauw and De Vos (2010) demonstrate that Millennials have high expectations in areas such as job content, training, career development, and financial rewards. Gresse, Linde and Schalk (2013) found similar results regarding university students, identifying expectations such as attractive remuneration, benefits, personal skill development opportunity, and career opportunity. According to $\mathrm{Ng}$, Schweitzer and Lyons (2010) the most important Millennial expectations when choosing employment are career advancement, work variety, and challenge. Some studies $(\mathrm{Ng}$, Schweitzer \& Lyons, 2010; Lub et al., 2012) indicate that well-being, respect, and work-life balance are hugely important for Millennials. Furthermore, Cennamo and Gardner (2008) state that Millennials have high expectations regarding social involvement and a good relationship with supervisors and co-workers. Moreover, Dziewanowska, Pearce and Zupan (2016) confirmed that young business students have high expectations about stability from employers. According to Todorovič and Pavićević (2016), students consider good working conditions and work environment as important expectations. 


\subsection{Anticipatory psychological contract}

The APC (De Hauw \& De Vos, 2010) is an important theoretical framework for understanding Millennials' expectations with respect to their future employment. Ruchika and Prasad (2019) consider APC as a crucial factor in the final employment decision of a candidate. They define APC as a mental map that prospective employees form about an organisation. It consists of promises prospective employees want to make to their future employers and obligations they seek in return (De Hauw \& De Vos, 2010). Similarly, some authors argue that before future employees commence formal employment, they already have a mental model regarding their expectations of their employer, which further affects their choice of future employment (Rousseau, 2001; Gresse, Linde \& Schalk, 2013).

The APC is formed in the period preceding organisational entry, when job seekers develop expectations regarding their potential employer and employment relationship (De Vos, De Stobbeleir \& Meganck, 2009). Knowledge and information gathered by the individuals when choosing their prospective employer play a significant role in forming APC (Rushika \& Prasad, 2019). According to Stoilkovska and Markovič (2015), information from organisations on their employment practices has become important in shaping the APC. Dziewanowska, Pearce and Zupan (2016) stated that employers also influence APC formation through internships and cooperation with universities; furthermore, the socio-economic context plays an important role in APC formation.

Based on the content-based typology of the psychological contract, Lub et al. (2016) distinguish between the following five dimensions of APC fulfilment: job content, career development, social atmosphere, the fairness of organisational policies, and rewards. De Vos, De Stobbeleir and Meganck (2009) also introduced five dimensions of employer obligations: Interesting job content and career opportunities (related to work-intrinsic types of incentives), social atmosphere and work-life balance (related to the job context), and financials (related to the material aspects).

Gresse, Linde and Schalk (2013) have proposed a structural anticipatory psychological model involving an expectation of both individual and general prospective employees, as well as the factors influencing these expectations. The individual expectations include an attractive salary, benefits, employee assistance, personal skill development opportunities, status in the workplace, and mobility opportunity. General expectations include a reasonable salary, necessity benefits, reasonable conditions of employment and environment, employee development and well-being, job-related skills development, and respect in the workplace. Both the modified dimensional model of the APC and the structural anticipatory psychological model were used in this study.

The following research questions were developed from the literature review:

RQ 1: What expectations do business university students have regarding their future employment?

RQ 2: To what extent do selected companies respond to the expectations business university students have regarding their future employment?

\section{Methodological approach}

This study is based on a two-phase approach. Phase one employed the Delphi method to identify Millennial students' expectations regarding their future employer and establish consensus on these expectations. Phase two conducts a content analysis to assess the extent to which companies fulfil students' expectations. Thus, to provide a complete picture of the surveyed problem, quantitative and qualitative elements were used in both methods. 


\subsection{Phase One-Delphi study}

Delphi method was used to address the first research question (RQ1). Delphi is a formal consensus method and a systematic means for measuring and developing consensus among participants regarding a particular topic (Linstone, \&Turoff, 1975; Green, 2014). Using the Delphi method, researchers can obtain accurate data by means of questionnaires distributed to a group of participants (experts). The Delphi Method is accepted as a useful method for solving problems, as a planning tool for forecasting future trends, and for recruitment purposes (Nevo, \& Chan, 2007, Humphrey-Murto, \& de Wit, 2019). This method uses a set of carefully designed questionnaires with summarised information and feedback of opinions derived from earlier responses of participants to gain new information about a particular topic (Green, 2014). The Delphi process is conducted over several rounds, initial and subsequent (Geisser, Alschuler, \& Hutchinson, 2011). Some authors suggest that the number of rounds for Delphi should be determined a priori; others, however, suggest that the process should stop when an agreement has been reached (Humpphrey-Murto, \& de Wit, 2018). In this study, three rounds were undertaken (for detailed description see below sub-chapter 3.1).

To measure the degree of consensus in the ranking of the items across all participants within an expert panel, Kendall's coefficient of concordance (W) in Equation (1) is applied in the third round. Kendall's W ranges from 0 (no agreement) to 1 (complete agreement).

$$
\mathrm{W}=\frac{\Sigma x^{2}-\frac{(\Sigma x)^{2}}{\mathrm{n}}}{\frac{1}{12} k^{2} *\left(n^{3}-\mathrm{n}\right)}
$$

To test the significance of W for results of Delphhi study, the formula (2) was used.

$$
x^{2}=W k(n-1)
$$

Next, linear transformation of $\mathrm{W}$ is applied. Spearman correlation is given by formula (3).

$$
\mathrm{r}=\frac{\mathrm{nW}-1}{\mathrm{n}-1}
$$

\section{Panel Selection}

The selection of the panel of experts is a critical aspect of the Delphi method (Pollard, C., \& Pollard, R. 2004). Expert panel selection in this study was based on the following criteria: the participant is a final-year business student (bachelor's or master's programmes) and is seeking employment. The Delphi panel in this study consisted of 87 final-year faculty of economics students, of which 38 were enrolled in the master's programme and 49 in the bachelor's programme. All students represented the Millennial generation (they were born before the year 2000).

\subsection{Phase two - Content analysis}

To address the second research question (RQ2) a content analysis of the company information in job-fair catalogues was employed. Company information included in job-fair catalogues can help in the decision process of applicants. Content analysis is a research technique that employs systematic and quantitative description of the content (Berelson, 1952). 
Before the analysis, coding rules were developed and pretested on a sample of the text by two coders. Afterwards, some items were removed, and others were added to the given categories. Thus, to obtain a consensus on the coding process, both coders separately analysed information from the chosen company profiles and placed them into the following eight categories: benefits, social atmosphere, training opportunities, career development, the stability of the company, job security, work-life balance, and rewards. They were derived from the modified dimensional model of the APC contract (De Vos, De Stobbeleir, \& Meganck, 2009; Lub et al., 2016), the structural anticipatory psychological model of Gresse, Linde and Schalk (2013), and the Delphi study findings.

\section{Sample}

For this study, job-fair catalogues from 2017 and 2018 were chosen. These catalogues were designed for the career fairs at the Czech Technical University and the University of West Bohemia, as well as the students participating in the career fairs. Both universities are among the largest universities in the Czech Republic. The selection of the company profiles included in these job-fair catalogues was based on the following inclusion criteria: a) The company profile must be primarily focused on searching for prospective employees and b) the target group of potential employees must be business, economics, and management students seeking a job. A total of 152 company profiles (65 in 2017 and 87 in 2018) were included in the content analysis. These profiles were published by 111 companies, of which 39 companies were included in both the 2017 and 2018 catalogues. The sample of analysed company profiles comprised $74 \%$ large enterprises and $26 \%$ medium and small enterprises.

\section{Conducting research and results}

\subsection{Delphi study}

This subchapter presents the findings of three rounds Delphi study. The first round (initial stage) constructed the issues related to the research. In this case, the participants were asked to indicate items that are important for young people when looking for employment. More particularly, the following open-ended question was asked: 'What expectations do you have of future employers in business fields while selecting them?' In the first round, students of the Master's programme $(n=38)$ indicated 42 items. Students of the Bachelor's programme $(n=$ 49) listed 29 items. Some of them were further aggregated. For example, 'working environment' and 'working equipment' were grouped under 'working environment or equipment', and 'language courses' were included in 'training opportunities'. Two items with very low records were not included in the second round of questioning. The final list included 21 items for students of the Master's programme and 22 for students of the Bachelor's programme. We intended to leave the items in the original form as reported by the participants and only sort them according to the item importance point totals. That is, presented items represent the point of view of students on their expectations regarding future employment before COVID-19 pandemic in academic year 2018/2019.

The second round provided the participants (experts) with feedback from the first round and presented them with a questionnaire. Participants were then asked to rate the items on the questionnaire using a predetermined 5-point Likert scale ranging from 'Not at all important' to 'Very important'. The Delphi moderator applied measures of central tendency to determine consensus from the second round. Table 1 presents the items obtained from the first round of questioning in the order of the second round for both groups of participants. That is, items are 
sorted in order of importance. Thus, the list shows that an attractive and appropriate salary was the most important expectation for both group of students, followed by benefits and career opportunities for master's programme students, and flexible working hours and career opportunities for bachelor's programme students. Table 1 also contains descriptive statistics for the items rated in the third round.

Table 1. Data from expert panels, rounds 2 and 3

\begin{tabular}{|c|c|c|c|c|c|c|c|c|c|}
\hline \multicolumn{5}{|c|}{ Students of the Master's programme } & \multicolumn{5}{|c|}{ Students of the bachelor's programme } \\
\hline \multicolumn{2}{|c|}{$\begin{array}{c}\text { Round } 2-\text { The final rank } \\
\text { of items }\end{array}$} & \multicolumn{3}{|c|}{$\begin{array}{c}\text { Round } 3 \text { - Descriptive } \\
\text { statistics } \\
\end{array}$} & \multicolumn{2}{|c|}{$\begin{array}{l}\text { Round } 2-\text { The final } \\
\text { rank of items }\end{array}$} & \multicolumn{3}{|c|}{$\begin{array}{c}\text { Round } 3 \text { - Descriptive } \\
\text { statistics } \\
\end{array}$} \\
\hline Rank & Items & $\begin{array}{l}\text { Sum } \\
\text { of } \\
\text { order }\end{array}$ & Avg. & $\begin{array}{l}\text { Std. } \\
\text { Dev. }\end{array}$ & Rank & Items & $\begin{array}{l}\text { Sum of } \\
\text { order }\end{array}$ & Avg. & $\begin{array}{l}\text { Std. } \\
\text { Dev. }\end{array}$ \\
\hline 1 & $\begin{array}{l}\text { Appropriate } \\
\text { salary }\end{array}$ & 67 & 1.76 & 1.42 & 1 & $\begin{array}{l}\text { Attractive } \\
\text { salary }\end{array}$ & 174 & 3.55 & 3.34 \\
\hline 2 & Benefits & 226 & 5.95 & 3.88 & 2 & $\begin{array}{l}\text { Flexible } \\
\text { working hours }\end{array}$ & 351 & 7.16 & 6.02 \\
\hline 3 & $\begin{array}{l}\text { Career } \\
\text { opportunities }\end{array}$ & 222 & 5.84 & 4.98 & 3 & $\begin{array}{l}\text { Career } \\
\text { opportunities }\end{array}$ & 339 & 6.92 & 5.73 \\
\hline 4 & $\begin{array}{l}\text { Training } \\
\text { opportunities }\end{array}$ & 357 & 9.39 & 5.43 & 4 & Benefits & 625 & 12.76 & 5.63 \\
\hline 5 & $\begin{array}{l}\text { A good and } \\
\text { friendly team }\end{array}$ & 218 & 5.74 & 3.37 & 5 & $\begin{array}{l}\text { Fair attitude } \\
\text { towards } \\
\text { employees }\end{array}$ & 467 & 9.53 & 4.79 \\
\hline 6 & $\begin{array}{l}\text { Working } \\
\text { environment and } \\
\text { equipment }\end{array}$ & 410 & 10.79 & 3.89 & 6 & Helpfulness & 626 & 12.78 & 5.25 \\
\hline 7 & Home office & 328 & 8.63 & 5.71 & 7 & $\begin{array}{l}\text { A good and } \\
\text { friendly team }\end{array}$ & 323 & 6.59 & 4.93 \\
\hline 8 & $\begin{array}{l}\text { Flexible working } \\
\text { arrangements }\end{array}$ & 396 & 10.42 & 5.03 & 8 & $\begin{array}{l}\text { Open } \\
\text { communicatio } \\
\mathrm{n}\end{array}$ & 489 & 9.98 & 4.27 \\
\hline 9 & $\begin{array}{l}\text { Personal } \\
\text { development }\end{array}$ & 364 & 9.58 & 5.20 & 9 & $\begin{array}{l}\text { Training } \\
\text { opportunities }\end{array}$ & 652 & 13.31 & 5.16 \\
\hline 10 & $\begin{array}{l}\text { Stability of the } \\
\text { company }\end{array}$ & 407 & 10.71 & 4.30 & 10 & $\begin{array}{l}\text { Opportunities } \\
\text { for self- } \\
\text { realization }\end{array}$ & 543 & 11.08 & 5.26 \\
\hline 11 & $\begin{array}{l}\text { A human } \\
\text { approach towards } \\
\text { employees }\end{array}$ & 424 & 11.16 & 4.28 & 11 & $\begin{array}{l}\text { A good } \\
\text { working } \\
\text { atmosphere }\end{array}$ & 422 & 8.61 & 5.10 \\
\hline 12 & Full-time contract & 468 & 12.32 & 5.28 & 12 & $\begin{array}{l}\text { Working } \\
\text { environment } \\
\text { and equipment }\end{array}$ & 710 & 14.49 & 5.47 \\
\hline 13 & $\begin{array}{l}\text { Travel } \\
\text { opportunities }\end{array}$ & 607 & 15.97 & 5.13 & 13 & $\begin{array}{l}\text { A meaningful } \\
\text { and } \\
\text { challenging } \\
\text { job }\end{array}$ & 375 & 7.65 & 6.21 \\
\hline 14 & $\begin{array}{l}\text { Appreciation for } \\
\text { good work }\end{array}$ & 400 & 10.53 & 4.42 & 14 & $\begin{array}{l}\text { Variety in } \\
\text { work }\end{array}$ & 596 & 12.16 & 5.56 \\
\hline 15 & Variety in work & 537 & 14.13 & 4.83 & 15 & $\begin{array}{l}\text { Trustworthy } \\
\text { colleagues }\end{array}$ & 579 & 11.82 & 4.93 \\
\hline 16 & $\begin{array}{l}\text { Respect for one } \\
\text { another }\end{array}$ & 490 & 12.89 & 4.86 & 16 & $\begin{array}{l}\text { Care about } \\
\text { employee as } \\
\text { individual } \\
\end{array}$ & 690 & 14.08 & 4.96 \\
\hline 17 & $\begin{array}{l}\text { Open } \\
\text { communication }\end{array}$ & 492 & 12.95 & 4.27 & 17 & Professionalism & 687 & 14.02 & 4.63 \\
\hline
\end{tabular}




\begin{tabular}{llllllllll}
\hline 18 & Work-life balance & 579 & 15.24 & 4.56 & 18 & $\begin{array}{l}\text { Respect for } \\
\text { one other }\end{array}$ & & 13.59 & 4.38 \\
\hline 19 & Extra holiday & 568 & 14.95 & 5.37 & 19 & $\begin{array}{l}\text { Informal } \\
\text { approach } \\
\text { towards } \\
\text { employees }\end{array}$ & 712 & 14.53 & 5.96 \\
\hline 20 & Company car & 687 & 18.08 & 3.76 & 20 & Great superior & 561 & 11.45 & 5.75 \\
\hline 21 & Creativity in work & 547 & 14.39 & 6.21 & 21 & $\begin{array}{l}\text { A highly } \\
\text { prestigious } \\
\text { employer }\end{array}$ & 819 & 16.71 & 5.23 \\
\hline
\end{tabular}

Source: own data

The third round provided feedback from the previous round to reach a final consensus or indicate whether a consensus can be reached (Green, 2014). In our case, the participants were asked to indicate their agreement with the list of items formed in round two. The highest agreement in the ranking was an appropriate salary, a good and friendly team, benefits (by students of the Master's programme), and an attractive salary (by students of Bachelor's programme). The highest disagreement in the ranking was for creativity in work (by students of the Master's programme), a meaningful and challenging job, and flexible working hours (by students of the Bachelor's programme). The final top ten items for both groups of students are displayed in Table 2.

Table 2. Top 10 final items, student's expectations regarding future employment

\begin{tabular}{lll}
\hline $\begin{array}{c}\text { Students of the Master's programme, } \\
\mathrm{n}=38\end{array}$ & $\begin{array}{c}\text { Students of the Bachelor's programme, } \\
\mathrm{n}=49\end{array}$ \\
\hline - & Appropriate salary & - Attractive salary \\
- Friendly team & - A good and friendly team \\
- Benefits & - Career opportunities \\
- Career opportunities & - Flexible working hours \\
- Home office & - A meaningful and challenging job \\
- Training opportunities & - Pleasant atmosphere \\
- Personal development & - Fair attitudes towards employees \\
- Flexible working arrangements & - An informal approach towards \\
- Appreciation for good work & & employees \\
- & - Stability of the company & - Open communication \\
\end{tabular}

Source: own data

Kendall's W (1) for students of the Bachelor's programme is 0.335 , and that for students of the Master's study programme was 0.409 . These calculated values indicate some level of agreement between participants (judges).

The calculated value (2) for both groups is greater than the critical value (Master's level, $278,12>34,410$, Bachelor's level, 325,143 > 32,671, $\alpha=0,05)$; thus, we can declare statistical significance and reject the null hypotheses.

The average (Spearman) correlation coefficient in Equation (3), computed on the ranks of all pairs of participants, is 0.391 for students of the Master's level and 0.381 for students of the Bachelor's level. That is, $r$ for both groups of respondents yields almost the same results and indicates a moderate consensus. 
These findings provide evidence that some Millennial expectations (such as financial reward, a good team, and career development) are largely intrinsic to this generation. It confirms the idea that Millennials are inclined to have similar expectations regarding their future employment (Lub et al., 2016). At the same time, consistent with previous research (De Hauw, \& De Wos, 2010), these expectations are also affected by individual differences.

\subsection{Content analysis}

This section reports descriptive statistics for each category in the analysed company profiles and results of analysis of total year-on-year changes in the frequency of these categories.

Table 3. Records of categories in company profiles in 2017 and 2018

\begin{tabular}{|c|c|c|c|c|c|c|}
\hline \multirow[b]{3}{*}{$\begin{array}{c}\text { Content analysis } \\
\text { Dimension or } \\
\text { Categories }\end{array}$} & \multicolumn{3}{|c|}{2017} & \multicolumn{3}{|c|}{2018} \\
\hline & \multicolumn{3}{|c|}{$\begin{array}{c}\text { Frequency/Percentage of recorded items in } \\
\text { each category }\end{array}$} & \multicolumn{3}{|c|}{$\begin{array}{l}\text { Frequency/Percentage of recorded } \\
\text { items in each category }\end{array}$} \\
\hline & No record & $\begin{array}{c}\text { Total No of } \\
\text { records } \\
1+\text { more } \\
\end{array}$ & $\begin{array}{l}2+\text { more } \\
\text { records }\end{array}$ & no record & $\begin{array}{l}\text { Total No of } \\
\text { records } \\
1+\text { records } \\
\end{array}$ & $\begin{array}{l}2+ \\
\text { records }\end{array}$ \\
\hline $\begin{array}{l}\text { Company reputation } \\
\text { and image }\end{array}$ & $2 / 3 \%$ & $63 / 97 \%$ & $39 / 60 \%$ & $2 / 2 \%$ & $85 / 98 \%$ & $39 / 45 \%$ \\
\hline Job content & $12 / 18 \%$ & $53 / 82 \%$ & $35 / 54 \%$ & $21 / 24 \%$ & $66 / 76 \%$ & $35 / 40 \%$ \\
\hline Career development & $16 / 25 \%$ & $49 / 75 \%$ & $27 / 42 \%$ & $25 / 29 \%$ & $62 / 71 \%$ & $27 / 31 \%$ \\
\hline Work-life-balance & $18 / 28 \%$ & $47 / 72 \%$ & $*$ & $28 / 32 \%$ & $59 / 68 \%$ & $*$ \\
\hline Training opportunities & $23 / 35 \%$ & $42 / 65 \%$ & $16 / 25 \%$ & $39 / 45 \%$ & $48 / 55 \%$ & $16 / 18 \%$ \\
\hline Social atmosphere & $24 / 37 \%$ & $41 / 63 \%$ & $17 / 26 \%$ & $42 / 48 \%$ & $45 / 52 \%$ & $17 / 20 \%$ \\
\hline Benefits & $26 / 40 \%$ & $39 / 60 \%$ & $20 / 31 \%$ & $24 / 28 \%$ & $63 / 72 \%$ & $20 / 23 \%$ \\
\hline Financial reward & $36 / 55 \%$ & $29 / 45 \%$ & $*$ & $30 / 34 \%$ & $57 / 66 \%$ & $*$ \\
\hline
\end{tabular}

Source: own data

Table 3 shows the total frequencies of the records in each category in the analysed company profiles. From the table, it is evident that company reputation and image is the most frequently occurring category in company profiles in both years. Particularly, $97 \%$ and $98 \%$ of company profiles included at least one item in 2017 and 2018, respectively. Furthermore, 60\% and $45 \%$ had at least two items in this category in 2017 and 2018, respectively. This category was also the only one to appear in nearly every company profile. The second most popular category was job content. This category was presented in $82 \%$ of the company profiles in 2017 and $76 \%$ in 2018 . The third most popular category was career development, accounting for $75 \%$ of company profiles in 2017 and $71 \%$ in 2018. In the categories of career development and work-life balance, there has been a slight decrease in the number of companies that mentioned career development in the analysed profiles.

The least occurring category in 2017 was financial reward, with only $45 \%$ of the company profiles including this category. However, in 2018, $60 \%$ of company profiles included this category, and it ranked higher than training opportunities and social atmosphere. Similarly, the category of benefits occurred in $60 \%$ of company profiles in 2017 . However, in 2018, it was in $72 \%$ of company profiles. Thus, this category was ranked higher than career development, work-life balance, training opportunities, social atmosphere, and financial reward. These changes indicate that companies now place greater emphasis on these two categories.

To measure the significance of year-on-year changes in the frequency of given categories, we used a two-tailed binomial test. The binomial test is used to compare the 
frequency of cases formed in two categories of dichotomous variables (Bryman \& Cramer, 2005).

Table 4. Statistical results of the Binomial test

\begin{tabular}{|c|c|}
\hline Significance level: & .05 \\
\hline \multicolumn{2}{|c|}{ Two-tailed hypothesis } \\
\hline Total count: & 21 \\
\hline Positive signs count $m+:$ & 11 \\
\hline Negative signs count m-: & 10 \\
\hline Z-score calculation & $(11-10.5) / \sqrt{5} .25$ \\
\hline \multicolumn{2}{|c|}{ Z-value: $0.21822 ; \mathrm{p}$-value 0.82726} \\
\hline & \\
\hline
\end{tabular}

Source: own data

Based on the Binomial test results (Table 4), an alternative hypothesis was rejected, and a null hypothesis was, therefore, confirmed. Thus, we can conclude that the year-on-year changes did not have a significant impact on the change in the shares of the categories as a whole. Overall, there were 11 positive changes (share growth) and 10 negative changes (share drop). The results also strongly confirm the p-value, which reaches 0.83 .

Recognising the relative statistical weakness of the binomial test (Robertson, \& Kaptain, 2016), a statistically stronger Wilcoxon pair test was used to verify the obtained results. The calculation of the Wilcoxon pair test is based on the pair values of two measurements on one sample: $\mathrm{X}$ and $\mathrm{X}^{\prime}$. In contrast to the Binomial test, the differences are compared. Non-zero differences are, therefore, arranged in ascending order in absolute values (Walker, 2013).

Table 5. Statistical results of Wilcoxon pair test

\begin{tabular}{lc}
\hline Significance level: & .05 \\
\hline Sample size $(\mathrm{n}):$ & Two-tailed hypothesis \\
\hline Sum. of positive ranks $W+:$ & 21 \\
\hline Sum. of negative ranks $W-:$ & 122 \\
\hline W-value: & 109 \\
\hline Critical value for $\mathrm{W}$ at $\mathrm{n}=19(\mathrm{p}<.05)$ & 85 \\
\hline Mean $(\mathrm{W}):$ & 49 \\
\hline Standard deviation $(\mathrm{W}):$ & 115.5 \\
\hline
\end{tabular}

\section{Source: own data}

The results of the Wilcoxon pair test (Table 5) confirm that, between 2017 and 2018, there was no significant change in the occurrence frequency of examined categories. Therefore, it is still possible to confirm the symmetrical distribution of the differences in the shares of the individual categories. A high p-value of 0.81 confirms the results.

In summary, both tests show that the year-on-year effect did not have a significant effect on the occurrence frequency of the examined categories. However, this does not mean there will be no year-on-year changes, as confirmed by the analysis of the individual categories.

\section{Discussion}

This study provides insight into the expectations of Millennial students when selecting their prospective employer and how companies respond to these expectations. Moreover, the 
fulfilment of several dimensions of the APC such as career development, job content, company reputation and image, work-life balance, training opportunities, social atmosphere, benefits, and financial reward from the company perspective has been explored. These issues were explored by formulating two research questions.

Research question 1: What expectations do business university students have regarding their future employer? This question plays an important role in understanding how Millennials arrive at preferences for future employment. Furthermore, to attract the right candidates, companies need to understand the expectations of prospective employees and work on them.

Overall, the results indicate high expectations regarding the career development, financial reward, and work-life-balance dimensions of APC. More particularly, both bachelor's and master's students expressed strong expectations regarding attractive and appropriate salary and career opportunities. This result is in line with that of previous research (Gresse, Linde, \& Schalk, 2013) in which these expectations were found to be largely intrinsic to Millennials. It is not also surprising that both groups of students want an employer that will meet their needs for flexibility, personal development, and self-realisation. However, although Generation $\mathrm{Y}$ is being characterised as the most individualistic generation (Lub et al., 2016), both groups of students identified a good and friendly team as an important expectation. Furthermore, among bachelor's programme students, this study found a higher need relating to social atmosphere expectations such as a pleasant atmosphere, fair attitudes towards employees, and an informal approach towards employees. This finding differs from that of De Hauw and De Vos (2010) who showed a lower expectation of Millennials regarding social atmosphere. A possible explanation is that their study was conducted during the time of recession, and this study is in a relatively prosperous and low unemployment period. By contrast, the benefits and stability of the company seem to be a requirement to master's students. These findings support previous studies (Lub et al., 2016).

In summary, no significant differences in expectations were found between master's and bachelor's students. More so, the results suggest that differences regarding expectations exist within subgroups of the students, which may be affected by a multitude of factors such as individual variables and formative experiences (De Haw, \& de Wos, 2010; Moore, Grunberg, $\&$ Krause, 2014). Moreover, the findings reveal that some students' expectations are influenced by the current economic context.

Research question 2: To what extent do companies respond to the expectations business university students have regarding their future employer? More particularly, we investigated the extent to which companies consider Millennials' employment expectations in their company profiles. This research question was approached from the APC perspective by analysing company profiles.

From the findings, it is evident that the fulfilment of APC dimensions from the company perspective is low, and some of the Millennial expectations are not given sufficient consideration. The results show that company reputation and image is the most frequently occurring category in the analysed company profiles, whereas Millennials place the greatest importance on financial rewards. In fact, financial reward was the least occurring category in 2017 in the analysed company profiles. Similarly, it was found that the social dimension and benefits are important for Millennial students, but the lower occurrence frequency of this category indicated that companies do not give priority to these dimensions. However, companies address dimensions such as job content, training opportunities, and work-life balance, which are important dimensions for Millennials.

In summary, it should be noted that companies insufficiently considered Millennial expectations in their company profiles and only partially respond to these expectations. This failure consequently creates difficulties in finding Millennial talent and negatively affects 
Millenials' intention to join a company. Thus, insight into this group of young people and their expectations of work, to design and implement effective and appropriate recruitment strategies, has become an important task for the organisations of today.

\section{Conclusion}

This study contributes to the growing body of research on Millennials and APC in the following ways. First, the study examines Millennials' (more specifically, final-year university students) expectations within an economic and national context different from those used in previous surveys. Second, the study employs APC dimensions as a relevant framework to assess the fulfilment of Millennial workplace expectations. Third, this study is one of the first to explore the extent to which companies consider Millennials' employment expectations in their company profiles in a period of economic prosperity. Finally, the study provides useful information for companies, CEOs, and HR managers to create retention strategies that are more likely to appeal to potential Millennial employees.

Finally, the study has important implications for companies, CEOs and HR managers. The findings show that Millennials place a strong emphasis on career development, financial reward and work-life-balance. They also prefer to work with company that provides pleasant atmosphere, fair attitudes towards employees, stability and benefits. On the other hand, the study found that companies do not give enough consideration to the Millennial expectations in their recruitment strategies. Thus, to take actions better tailor job offerings would enable companies to attract a Millennial worker. Moreover, a better understanding of workplace expectations of Millennials helps companies while designing their recruitment policy and procedures.

It should be noted that the current study has some limitations. First, we focused only on a select group of Millennial students. For a more complex picture, further research can encompass a more diverse group of students within this generation. Furthermore, additional factors such as type and level of education, preliminary professional experiences, and their impact on the APC need to be considered. Next, the study was performed within a single country, the Czech Republic. Therefore, to make generalisations, future research could take place in different countries. Finally, we used data from only two years. Thus, further studies should include data covering a longer period to explore the long-term effect of socio-economic and political changes.

\section{Acknowledgement}

This work was supported by Grant No. SGS-2020-015 "Research in selected areas of management and marketing of organisations in the context of demographic and technological changes".

\section{References}

Berelson, B. (1952). Content analysis in communication research. New York: Free Press. Bryman, A., \& Cramer, D. (2005). Quantitative Data Analysis with IBMSPSS 12 and 13: A Guide for Social Scientists. New York: Routledge, Taylor and Francis Group.

Catalogue iKariéra 2018. (2018). IASTE ČVUT Praha https://issuu.com/iaeste.cvut.praha/docs/ikariera_katalog_2018_final_new Accessed 15 Nowember 2018. 
Catalogue iKariéra 2017. (2017). IASTE ČVUT $\quad$ Praha https://issuu.com/iaeste.cvut.praha/docs/pruvodce_all Accessed 15 Nowember 2018.

Catalogue 23.Veletrh pracovních příležitostí [Career Fair]. (2018). SUS ZČU and AIESTE Czech Republic.

Catalogue 22. Veletr pracovních př́ležitostí [Career Fair]. (2017). SUS ZČU and AIESTE Czech Republic.

Cedefop. (2018). Insights into skill shortages and skill mismatch: learning from Cedefop's European skills and jobs survey. Luxembourg: Publications Office of the European Union.

https://www.skillsforemployment.org/edmsp1/groups/skills/documents/skpcontent/cdff/ mja4/ edisp/edmsp1_208220.pdf Accessed 10 January 2019.

Cennamo, L., \& Gardner, D. (2008). Generational differences in work values, outcomes, and person-organisation values fit. Journal of Managerial Psychology, 23(8), 891-906. https://doi.org/10.1108/02683940810904385.

De Hauw, S., \& De Vos, A. J. (2010). Millennials' career perspective and psychological contract expectations: does the recession lead to lowered expectations? Journal of Business and Psychology, 25(2), 293-302, https://doi.org/10.1007/s10869-010-9162-9.

De Vos, A., De Stobbeleir, K., \& Meganck, A. (2009). The relationship between career-related antecedents and graduates' anticipatory psychological contracts. Journal of Business and Psychology, 24(3), 289-298, https://doi.org/10.1007/s10869-009-9107-3.

Dziewanowska, K., Pearce, A., \& Zupan, N, (2016). Generation Y's expectations regarding their future employment relationships poses a challenge for their employers. Journal of Human Resource Management, 19 (1), 1-12.

Eisner, S. P. (2005). Managing Generation Y. SAM Advanced Management Journal, 70(4), 415.

Eurostat. (2018). Youth unemployment, Eurostat Statistics, https://ec.europa.eu/eurostat/statistics-

explained/index.php/Unemployment_statistics\#Youth_unemployment Accessed 30 June 2019. Accessed 15 March 2019.

Geisser, F. M., Alschuler, N. K., \& Hutchinson, R. (2011). A Delphi Study to Establish Important Aspects of Ethic Review. Dimensions of REC Review, 6(1), 21-24. https://doi.org/10.1525/jer.2011.6.1.21.

Green, A. R. (2014). The Delphi Technique in Educational Research. Sage Open, 1-8. https://doi.org/10.1177/2158244014529773.

Gresse, W., Linde, B., \&Schalk, R. (2013). Sense of deservingness: What are the entitlement beliefs of students in their anticipatory psychological contract? Management Review, 24(4), 270-288, https://doi.org/10.5771/0935-9915-2013-4-269.

Humphrey-Murto, S., \& de Wit, M. (2019). The delphi method - more research please. Journal of Clinical Epidemiology, 106, 136-139. https://doi.org/10.1016/j.jclinepi.2018.10.011

Linde, B., \& Gresse, W. (2014). Anticipatory Psychological Contracts of Undergraduates Management Students: Implications for Early Career Entitlement Expectations. In: Coetzee, M. (eds) Psycho-social career meta-capacities. Cham: Springer, 277-292, https://doi.org/10.1007/978-3-319-00645-1.

Linstone, H. A., \& Turoff, M. (1975). The Delphi Method. Techniques and Applications. Applications. Reading, MA: Addison-Wesley.

Lowe, D., Levitt, K. J., \& Wilson, T. (2011). Solutions for retaining generation Y employees in the workplace. IEEE Engineering Management Review, 39(2), 46-52, https://doi.org/10.1109/EMR.2011.5876174. 
Lub, X. D., Bal, P. M., Blomme, R., J., \& Schalk, R. (2016). One job, one deal...or not: do generations respond differently to psychological contract fulfillment?. The International Journal of Human Resource Management, 27(6), 653-680, https://doi.org/10.1080/09585192.2015.1035304.

Lub, X. D, Bijvank, N., Bal, P. M., Blomme, R., \& Schalk, R. (2012). Different or alike? Exploring the psychological contract and commitment of different generations of hospitality workers. International Journal of Contemporary Hospitality Management, 24(4), 553-573. https://doi.org/10.1108/09596111211226824.

Manpower Group (2016). Millennial Careers: 2020 Vision. https://www.manpowergroup.com/wps/wcm/connect/660ebf65-144c-489e-975c9f838294c237/MillennialsPaper1_2020Vision_lo.pdf?MOD=AJPERES Accessed 15 March 2019.

Mičík, M., \& Mičudová, K. (2018). Employer Brand Building: Using Social Media and Career Websites to Attract Generation Y. Economics and Sociology, 11(3), 171189. doi:10.14254/2071-789X.2018/11-3/11.

Moore, S., Grunberg, L., \& Krause, A. J. (2015). Generational Differences in Workplace Expectations: A Comparison of Production and Professional Workers. Current Psychology, 34(2), 346-362. https://doi.org/10.1007/s12144-014-9261-2.

Ng, E. S. W., Schweitzer, L., \& Lyons, S. T. J. (2010). New Generation, Great Expectations: A Field Study of the Millennial Generation. Journal of Business and Psychology, 25(2), 281-292. https://doi.org/10.1007/s10869-010-9159-4.

Nevo, D., \& Chan. D. Y. A. (2007). Delphi study of knowledge management systems: Scope and requirements. Information \& Management. 44(6), 583-597. https://doi.org/10.1016/j.im.2007.06.001.

OECD. (2019). Economic Surveys: Czech Republic, OECD 2018, https://www.oecd.org/eco/surveys/Czech-Republic-2018-OECD-economic-surveyoverview.pdf Accessed 10 January 2019.

OECD. (2020). Unemployment Rates. https://www.oecd.org/newsroom/unemployment-ratesoecd-update-september-2020.htm Accessed 13 September 2020.

Park, S., \& Park, S. (2018) Exploring the generation gap in the workplace in South Korea. Human Resource Development International, 21(3), 276-283. https://doi.org/10.1080/13678868.2017.1306769.

Parry, E., \& Urwin, P. (2010). Generational differences in work values: a review of theory and evidence. International Journal of Management Reviews, 13(1), 79-96. https://doi.org/10.1111/j.1468-2370.2010.00285.x

Pollard, C., \& Pollard, R. (2005). Research priorities in educational technology: A Delphi study. Journal of Research on Technology in Education, 37(2), 145-160.

Ramesh, G., \& Vasuki, K. (2013). Recognizing, rewarding and retaining gen-y work force for creating high performing organizations. Journal of Commerce, 4(3), 562-573.

Robertson, J., \& Kaptein, M. (2016). Modern Statistical Methods for HCI. Springer. https://doi.org/10.1007/987-3-319-26633-6.

Rousseau, D. M. (2001). Schema, promise and mutuality: The building blocks of the psychological contract. Journal of Occupational and Organizational Psychology, 74, 511-541. https://doi.org//10.1348/096317901167505,

Ruchika, \& Prasad, A. (2019). Untapped relationship between employer branding, anticipatory psychological contract and intent to join. Global Business Review, 20(1), 194-213. https://doi.org/10.1177/0972150917713897. 
Sutton, G., \& Griffin, M. A. (2004). Integrating expectations, experiences, and psychological contract violations: A longitudinal study of new professionals. Occupational and Organizational Psychology. 77(4), 493-514. https://doi.org/10.1348/0963179042596487

Stoilkovska, B. B., \& Markovic, Z. (2015). The role of optimism - pessimism in anticipatory psychological contract formation. Procedia-Social and Behavioral Sciences, 171,145152, https://doi.org/10.1016/j.sbspro.2015.01.100.

Thompson, C., \& Gregory, J. B. (2012). Managing Millennials: a framework for improving attraction, motivation, and retention. Psychologist-Manager Journal, 15(4), 237-246. https://doi.org/10.1080/10887156.2012.73.

Todorović, M., \& Pavićević, M. (2016). Bridge the gaps, retain the talented Millennials. Serbian Project Management Journal, 6 (1), 81-90.

Walker, I. (2013). Výzkumné metody a statistika [Research methods and Statistics]. Praha: Grada.

Weber, J. (2017). Discovering the Millennials' personal values orientation: a comparison to two managerial populations. Journal of Business Ethics, 143(3), 517-529. doi:10.1007/s10551-015-2803-1.

Wong, M., Gardiner, E., Lang, W., \& Coulon, L. (2008). Generational differences in personality and motivation: Do they exist and what are the implications for the workplace? Journal of Managerial Psychology, 23(8), 878-890. doi:10.1108/02683940810904376.

Zupan, N., Mihelič, K., K., \& Aleksić, A. (2018). Knowing me is the key: implications of anticipatory psychological contract for Millennials' retention. In: Coetzee M., Potgieter I., Ferreira N. (eds) Psychology of Retention. Cham: Springer. https://doi.org/10.1007/978-3-319-98920-4_15. 